\title{
Grief, Interrupted
}

\author{
Thomas William LeBlanc, M.D., M.A.
}

$\mathbf{I}^{\mathrm{N}}$ NTERNSHIP PRESENTED ME with countless opportunities to worry. The spectrum of concern varied widely, but rest assured there was always something for me to lose sleep about. Looking back, it was often a rather simple question, involving medication doses or routes of administration, but to a newly minted medical graduate everything feels substantial. Of all the dilemmas I faced though, these medication questions soon came to be my favorites. After all, there was usually a concrete answer, and it could be found in a drug database. Just 1 week into my postgraduate training I began to master many of these quandaries, having become quite adept at interpreting drug monographs and searching databases. I began to enter orders with ease and confidence, the latter not nearly justified at that time, but at least I knew how to renally dose antibiotics and make intravenous to oral conversions of many common medications. Despite this rapid growth, however, my worries hardly abated. There was always another terrifying experience looming around the corner, and at this point in my training even the seemingly "simple" things were horrifying. Shortness of breath became the bane of my existence one night, as I froze in terror, heart pounding in my chest, upon seeing an older patient wearing a facemask, perched in a classic "tripod" position to facilitate his respirations. Thankfully, the nurse knew what to do.

"He just received some blood products but did not get any pre-meds. Should I give some Benadryl ${ }^{\circledR}$ for a possible transfusion reaction?" she asked.

Sure, that sounded good to me. . . but what did I know? I had never seen a transfusion reaction before. I ordered up some Benadryl $^{\circledR}$, and sure enough the man got better! What a relief that was, although I felt like I needed an anxiolytic myself, if not a $\beta$-blocker for my internship-related situational tachycardia. I had survived what felt like another disaster, a defining moment, and had even learned something new . . . such is all in a typical day's work as an intern, though I could hardly take credit for it. Still, the proverbial elephant in the room remained: I had yet to see someone die. And of all the horrifying thoughts and worries that being an intern provoked within me, this was by far the worst. Not a day went by that I didn't think about it, especially since I was rounding on the solid tumor oncology service during that first month. It was inevitable, yet I knew not the day nor the hour.

I remember how they tried to teach us about death and dying in medical school. We learned how to facilitate end-oflife conversations by watching a role-play in the auditorium, and then practiced this difficult skill by talking with standardized patient actors. These were paid actors who pretended they had a serious illness, with whom we had to deliver a terminal diagnosis and discuss goals of care. To make matters worse, this was done in front of several of our peers, or was videotaped and later critiqued by them. Much like internship, these exercises were frightening in many ways, but they were also incredibly helpful. Still, they were lacking in a very significant, albeit unavoidable way. Namely, no one could recreate the experience of watching a patient die. There's no patient simulator for this.

Fast-forward to week 2 of internship. It was only my third call night, and I was still terrified each time my pager beeped. Signout time came around, and one by one the other interns stopped by to drop off their patient lists. My anxiety increased with each successive handoff, as I silently counted the number of patients that would be under my care that night. In the end, I was covering nearly the entire floor of the hospital, upwards of $40-50$ patients. This alone was enough to make me worry quite a bit, but not nearly as much as what another intern said next. "Mrs. G is not doing well, and just might die tonight. She's DNR/DNI," he said, circling this notation in large, black type on the signout sheet.

My stomach suddenly sank. I knew this time would come eventually, but this hardly helped me feel any more prepared to face the reality. Even the logistics of "diagnosing" death seemed mysterious to me. Believe it or not, no one ever taught me how to actually "pronounce" a patient dead, and I had certainly never seen it done. So much for the old adage of "see one, do one, teach one." For me it was more like, "do one and hope you don't screw it up."

And sure enough, a few hours later I received the dreaded page: "Doctor, the patient in room 9 looks much worse. I don't think there's much time left."

A wave of terror rolled over me, and I felt nauseated. The business of the wards came to a standstill, as I contemplated how to face this challenge.

"Thank you, I'll be there soon," I said, trying to hide the fear in my voice.

As a student, I was not only allowed, but mostly expected to "pass the buck" on these difficult issues. It was not my responsibility to be the point person, to communicate with families, or to sign anything official. Now things were different. I was an intern, a "real doctor." I still felt like an impostor, but was given a great deal of responsibility nonetheless.

Department of Medicine, Divisions of Hematology and Medical Oncology, Duke University Medical Center, Durham, North Carolina. 
Looking back, these difficult situations forced immense growth, but at the time they were always terrifying. Snapping back to reality, I realized that the proverbial "buck" now stopped with me, at least until the attending arrived in the morning.

As I walked slowly toward the room, my mind raced with thoughts and fears. Would family be there? Could I face a large group? Would they know her prognosis? How could I comfort them? What would they ask me? Would I be able to answer their questions? Flipping through the chart, my eyes glazed over, too scared to process the information. Instead, I took a deep breath, tried to pull myself together, and opened the door.

What I saw next remains forever etched into my memory. Although I had never seen "death" before, this elderly woman clearly "looked like death." Thin as thin could be, her collarbones jutted out prominently, her ribs strikingly obvious. She looked like a skeleton. Her eyes were sunken in, face expressionless, and her breathing was erratic and labored. Despite the dim lighting, I was struck by her rather wild, wiry white hair, which jutted out whimsically from her scalp. A faint gurgling sound was audible with each respiration. She seemed lifeless already. Was there still a person there?

Looking up, a younger, smiling face greeted me. As I introduced myself, she placed a cool washcloth on the patient's face. The care she took in doing this simple act was practically palpable, clearly having been done in love and respect. Summoning up the courage, I asked if she had any questions, or if there was anything she needed. "No, thank you. I'm just glad to see that my sister's suffering is nearly over."

Thinking back to those standardized patient days, I pulled up a chair and sat down. "Do you think she's comfortable?" I asked. She went on to tell me about how much her sister had suffered with this cancer, battling for over 10 years with what started as a lump in her breast, and had since spread to her bones. Initially, I worried a bit about what to say next, but I soon realized that I hardly had to say anything at all; I just needed to listen! A sense of calm came over me, and it felt as if the world outside that hospital room ceased to exist, and time stood still. By some miracle, my pager kept quiet too. She told me many stories about her sister, which I sadly cannot remember today, though I wish I could. However, I will never forget the profundity of the time we spent together. It seemed almost sacred, and was like nothing I had experienced before. This was hardly terrifying, I realized; it was special.

As we spoke, the patient's breathing pattern slowed and became more erratic. It stopped, but then came another sudden gasp, a good 20 seconds later. The gasp startled me, and I nearly fell out of the chair. Was she dead yet? What should I do? How would I know? I placed my stethoscope on her chest and listened. Even this simple task was difficult due to her profound emaciation. There were no sounds, and never in my life have I been so struck by silence. Another quick breath came, and then stopped. I listened for several minutes, probably much longer than necessary, but I had to be sure that the patient was dead. After a while, there was nothing but silence.

"I'm sorry," I said. "She's gone." I feigned confidence, half expecting to see the patient take another shallow breath at any second. . . I was hardly so sure initially. "Thank you," said her sister, "for everything you all have done for her."

The significance of this moment overtook me. A person's life had just come to a close. I fought back the emotion, as tears threatened to brew beneath my eyelids. As far as I knew, doctors did not cry with their patients. Still, I felt the need to do something, to somehow process this experience. I couldn't just go back to work, to the barrage of pages, requests for laxatives, and cross-cover emergencies. Alone with my thoughts, the isolation of the call room provided some solace. I turned off the lights, lay back on the bed, and took a slow, deep breath. Why had this woman thanked me, when her sister had just died? What made this patient's death feel like such a sacred, special occasion? Why did I feel so comfortable after only a short while, despite having no idea what to do or expect? What should I do to process all this?

Unfortunately, a barrage of pages soon pulled me from my own grief. . . I had to go back to work, and would consequently spend much time throughout intern year processing these feelings and questions.

To this day, I have not forgotten what it was like walking into that room during my second week of internship, nor have I forgotten that profound feeling of sacredness at witnessing the final moments of a human life. I carry this powerful experience with me each day, and have experienced it again many times since then. Despite my lack of preparedness to face such a situation, it has become a truly defining moment of sorts, which has altered the course of my career and my interests. Because of this experience, I no longer shy away from death, and indeed have chosen a career in oncology and palliative medicine.

Thank you, to the patient whose name I have long forgotten, but whose spirit is with me always. You have taught me more in 1 hour than I could have ever hoped to learn through a mountain of textbooks. You have shown me what a privilege it is, to care for patients at the end of life.

Address correspondence to: Thomas William LeBlanc, M.D., M.A. Department of Medicine Divisions of Hematology and Medical Oncology Duke University Medical Center Box 3841

Durham, NC 27710

E-mail: thomas.leblanc@duke.edu 